Imperial Russia 
Also by John Paxton

CALENDAR OF WORLD HISTORY

ENCYCLOPEDIA OF RUSSIAN HISTORY

From the Christianization of Kiev to the Break-up of the USSR

EUROPEAN POLITICAL FACTS OF THE TWENTIETH CENTURY (with Chris Cook)

PENGUIN ENCYCLOPEDIA OF PLACES 


\section{Imperial Russia}

A Reference Handbook

John Paxton 


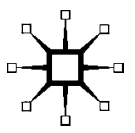

(C) John Paxton 2001

Softcover reprint of the hardcover 1st edition 2001 978-0-333-76393-3

All rights reserved. No reproduction, copy or transmission of this publication may be made without written permission.

No paragraph of this publication may be reproduced, copied or transmitted save with written permission or in accordance with the provisions of the Copyright, Designs and Patents Act 1988, or under the terms of any licence permitting limited copying issued by the Copyright Licensing Agency, 90 Tottenham Court Road, London W1P OLP.

Any person who does any unauthorised act in relation to this publication may be liable to criminal prosecution and civil claims for damages.

The author has asserted his right to be identified as the author of this work in accordance with the Copyright, Designs and Patents Act 1988.

First published 2001 by

PALGRAVE

Houndmills, Basingstoke, Hampshire RG21 6XS and

175 Fifth Avenue, New York, N. Y. 10010

Companies and representatives throughout the world

PALGRAVE is the new global academic imprint of

St. Martin's Press LLC Scholarly and Reference Division and

Palgrave Publishers Ltd (formerly Macmillan Press Ltd).

Outside North America

ISBN 978-1-349-41462-8

ISBN 978-0-230-59872-0 (eBook)

DOI $10.1057 / 9780230598720$

In North America

ISBN 978-1-349-41462-8

This book is printed on paper suitable for recycling and made from fully managed and sustained forest sources.

A catalogue record for this book is available from the British Library.

Library of Congress Cataloging-in-Publication Data

Paxton, John.

Imperial Russia : a reference handbook / John Paxton.

p. cm.

Includes bibliographical references and index.

ISBN 978-1-349-41462-8 (cloth)

1. Russia-Handbooks, manuals, etc. I. Title.

DK14 .P39 2000

947-dc21

$\begin{array}{rrrrrrrrrr}10 & 9 & 8 & 7 & 6 & 5 & 4 & 3 & 2 & 1\end{array}$

$\begin{array}{llllllllll}10 & 09 & 08 & 07 & 06 & 05 & 04 & 03 & 02 & 01\end{array}$ 


$$
\text { for }
$$

Cherrill, Elizabeth, George,

Joseph, Patrick, Samuel and Thomas 
This page intentionally left blank 


\section{Contents}

Preface $\quad$ xiii

The Romanov Dynasty $\quad \mathrm{xV}$

Maps Xvi

Introduction: Imperial Russia $\quad 1$

1. Tsars and Important Advisers and Ministers (1533-1917) 5

2. The Regencies and the Problems of Dynastic Succession (1533-1917) 9

3. Political Chronologies 14

Ivan IV, Fedor I, Boris Godunov (1533-1605) 14

Time of Troubles (1605-1613) 15

Michael, Alexis, Fedor III (1613-1682) 16

Peter I (the Great) (1682-1725) 20

Catherine I, Peter II, Anne, Ivan VI, Elizabeth, Peter III (1725-1762) 23

Catherine II (the Great) (1762-1796) 24

Paul (1796-1801) 26

Alexander I (1801-1825) 27

Nicholas I (1825-1855) 29

Alexander II (1855-1881) 30

Alexander III (1881-1894) 32

Nicholas II and Revolution (1894-1917) 33

Nicholas II's inheritance $\quad 33$

Chronology 34

4. The Influence of the West 41

The Westerner/Slavophile controversy $\quad 41$

Peter I's visits to Western Europe $\quad 42$

$\begin{array}{ll}\text { The Beard Tax } & 43\end{array}$

The founding of St Petersburg $\quad 44$

Catherine II (the Great) and the Philosophes 44

5. Political and Administrative Changes in Imperial Russia 46

Ivan IV (the Terrible) 46

Zemskii Sobor is convened 46

Creation of the Oprichnina 46

The 'Forbidden Year' 46 
$\begin{array}{ll}\text { Fedor I } & 46\end{array}$

Saint George's Day law 46

$\begin{array}{ll}\text { Michael } & 47\end{array}$

Emergency tax voted by Zemskii Sobor 47

Inventory of taxable land is taken 47

Alexis $\quad 47$

New legal code (Ulozhenie) 47

'Copper Revolt' 47

$\begin{array}{ll}\text { Peter I (the Great) } & 47\end{array}$

Reform of government and administration 47

Reform of the army and navy 48

The Table of Ranks (1722) 50

Catherine I, Peter II, Anne, Elizabeth, Peter III 52

Creation of the Supreme Privy (Secret) Council 52

'Conditions of Mitau' 53

Catherine II (the Great) 53

Marshals of the Nobility (1766) 53

Legislative Commission (1767-68) and Catherine's Nakaz 54

The Dvoryanstvo Charter (1785) 55

Charter to the Towns (1785) 56

Alexander I $\quad 56$

The State reforms of 1808-09 56

$\begin{array}{ll}\text { Nicholas I } & 57\end{array}$

The Creation of the Third Section or Department (the $\begin{array}{ll}\text { secret police) } & 57\end{array}$

Alexander II $\quad 58$

Reform of military service (1863) 58

Zemstva (local self-government) in 1864

Alexander III $\quad 59$

Counter-reforms $\quad 59$

$\begin{array}{ll}\text { Nicholas II } & 60\end{array}$

$\begin{array}{ll}\text { Creation of the Duma } & 60\end{array}$

$\begin{array}{ll}\text { The Vyborg Manifesto } & 61\end{array}$

Political groupings in the dumas $\quad 62$

6. Religion 65

Russia's conversion to Christianity 65

Chronology 1569-1918 65

$\begin{array}{ll}\text { Orthodox Church } & 76\end{array}$

$\begin{array}{ll}\text { Old Believers } & 76\end{array}$

$\begin{array}{ll}\text { Georgian Orthodox Church } & 77\end{array}$

$\begin{array}{ll}\text { Armenian Church } & 77\end{array}$ 
Baptists

Jews

Islam

7. Serfdom in Imperial Russia

Chronology 1640s-1918

The Pugachev Rebellion

Number of serfs in 1762

Peasant uprisings before emancipation

The edict of Emancipation of the serfs (1861)

Stolypin's agrarian reforms of 1911

Agricultural production

8. Social and Economic Progress 92

Population $\quad 92$

Ethnic composition $\quad 93$

Changing status of women 93

Government revenue and expenditure $\quad 97$

$\begin{array}{lr}\text { Money and banking } & 99\end{array}$

$\begin{array}{lr}\text { Industrial growth } & 100\end{array}$

$\begin{array}{ll}\text { Share capital of enterprises } & 101\end{array}$

Decision on Employment of Minors 102

Factory Regulations, $1886 \quad 102$

Operatives Working for Wages, 1804 and 1825

Industrial Disputes 1895-1913 104

Alcohol production 104

Cotton industry 104

$\begin{array}{ll}\text { Minerals } & 105\end{array}$

$\begin{array}{ll}\text { Salt } & 105\end{array}$

$\begin{array}{ll}\text { Petroleum production } & 106\end{array}$

$\begin{array}{ll}\text { Exports and imports in } 1901 & 106\end{array}$

$\begin{array}{lr}\text { Customs and duties } & 107\end{array}$

$\begin{array}{lr}\text { River and canal traffic } & 108\end{array}$

$\begin{array}{ll}\text { Railways } & 108\end{array}$

$\begin{array}{lr}\text { Weights and measures } & 110\end{array}$

9. The Rise of Radicalism 111

Monarchy and absolutism: an overview $\quad 111$

$\begin{array}{ll}\text { The Decembrists } & 112\end{array}$

$\begin{array}{lr}\text { Petrashevsky Circle } & 113\end{array}$

Liberation of Labour Group $\quad 114$

$\begin{array}{ll}\text { Land and Liberty Organisation } & 114\end{array}$

$\begin{array}{ll}\text { People's Freedom or Will } & 114\end{array}$ 
$\begin{array}{lr}\text { Nihilism } & 115\end{array}$

$\begin{array}{ll}\text { Pan-Slavism } & 115\end{array}$

$\begin{array}{lr}\text { Bund } & 115\end{array}$

Constitutional Democratic Party 116

Bloody Sunday and the Revolution of $1905 \quad 116$

Popular movements in $1905 \quad 118$

Dashnaktsutyun $\quad 118$

$\begin{array}{ll}\text { Anarchism } & 118\end{array}$

$\begin{array}{lr}\text { Menshevism } & 120\end{array}$

$\begin{array}{ll}\text { Bolshevism } & 121\end{array}$

February Revolution (1917) 121

Telegram of 27 February 1917 from Rodzyanko President of the State Duma to the tsar 121

Telegram of 28 February 1917 from General Alekseev Chief of Staff of the Supreme Commander to all the Commanders in Chief

Nicholas II abdicates 123

$\begin{array}{ll}\text { Provisional government } & 124\end{array}$

October Revolution (1917) 124

$\begin{array}{ll}\text { Murder of the ex-tsar } & 125\end{array}$

10. International Relations and the Expansion of Russia Overseas 126

$\begin{array}{ll}\text { Battles and Wars 1548-1918 } & 126\end{array}$

Alliances, Congresses, Conferences and Treaties 130

$\begin{array}{ll}\text { Army } & 132\end{array}$

Navy $\quad 133$

Russia and Sweden $\quad 133$

Great Northern War 133

Russo-Swedish War 1788-90 134

Russia and the Ottoman Empire 134

Russo-Turkish War 1768-74 134

Russo-Turkish War 1787-92 134

Russo-Turkish War 1806-12 135

Treaty of (Edirne) Adrianople (1829) 135

Crimean War (1853-56) 135

Danubian Principalities 136

Russo-Turkish War 1877-78 136

Russia and Poland 136

Partitions of Poland 136

$\begin{array}{ll}\text { Russia and France } & 138\end{array}$

The War of the Second Coalition 1799-1802 138

The War of the Third Coalition 1803-07 138 
French invasion of Russia 139

The Wars of Liberation 1813-14 140

Congress of Vienna 140

Russia and Japan 141

Russo-Japanese War (1904-05) 141

Russia and the First World War 142

Russia and Persia 143

Treaty of Turkmanchai 143

Russia and Prussia 143

Russia America (Alaska) 1741-1867 143

Russian expansion overseas 144

Russian Empire ethnic composition 147

11. Education and the Arts 149

Education 149

Libraries 154

Publishing 155

Alphabet and Transliteration $\quad 155$

Literature 155

Art 156

Ballet 157

Theatre 157

Architecture 158

12. Law, Crime and Punishment 160

Law 160

Chronology of punishments 162

Third Section (Department) 163

Okhrana 163

13. Press and Censorship 165

Newspapers and journals 165

Censorship 168

$\begin{array}{ll}\text { 14. Biographies } & 171\end{array}$

15. Glossary 221

16. Bibliography 241

Index 249 
This page intentionally left blank 


\section{Preface}

Imperial Russia: A Reference Handbook aims to provide an accessible reference tool for students, researchers, historians and Russian history enthusiasts. It covers the period from Ivan IV (the Terrible) to the death of Nicholas II.

There are many watersheds and turning points in Russian history, including Vladimir's conversion to Christianity in 988 AD, 'The Time of Troubles', the founding of St Petersburg by Peter I (the Great), the abolition of serfdom, the creation of the Third Section, in the twentieth century the establishment of the Duma, Lenin's return to Russia, the publication of the April Theses and the revolutions. The Handbook answers questions such as: Who were the Decembrists? What was the background of Aleksandr Kerensky and Grigory Rasputin? What is a duma? What was an arshin, desyatin, pood or verst? There are chronologies for each of the reigns and the Handbook explains important political and administrative changes, the influence of the West, religion, serfdom, and economic progress. Wars and international relations are succinctly explained as is the rise of radicalism and the revolutions of 1905 and 1917. Other sections deal with education, the arts, law, press and censorship. There are biographies which include the great, the eccentric, the wicked, the good and the talented, a glossary, a comprehensive bibliography, maps and an extended index.

As readers and writers know, transliteration problems arise in any book on Russia. I used the Library of Congress transliteration system, but it was necessary to break the rules from time to time. Certain forms, such as 'Alexei Sergeyevich' do not belong to the Library of Congress or to the British Standard schemes. Instead, they usually trace back to the idiosyncratic schemes of early translators who mixed equivalents, 'Alexis', with transliterations. Some idiosyncratic spellings, which as 'Tchaikovsky', are hallowed by tradition, and, of course, I have used English forms for such people as 'Catherine I (the Great)', and such places as 'Moscow'.

Dates also present confusion because until 1918, the Julian rather than the Gregorian calendar was used in Russia. Consequently, dates determined by the Julian calendar are twelve days behind the Gregorian calendar in the nineteenth century and thirteen days behind in the twentieth century. When Russia adopted the Gregorian systems, the Julian date 31 January became Gregorian date 14 February. In this Handbook I have used the old style, except for external events, where I have used new style throughout. The Handbook evolved over several years and the London Library was, as usual, extremely helpful and I have to thank once again my two friends Penny White and Dione Daffin for enormous help. 
Thanks are due to Yale University Press for permission to reproduce from $A$ Source Book for Russian History to 1917 by George Vernadsky and Ralph T. Fisher and to HarperCollins for permission to quote from Russia: People and Empire 1552-1917 by Geoffrey Hoskings.

Every effort has been made to trace all copyright holders but if any has been inadvertently overlooked, the author and publishers will be pleased to make the necessary arrangement at the first opportunity.

If errors are found they are my own and I shall be pleased, although sad at the time, to be alerted so that they can be corrected for future editions.

John Paxton

Bruton, Somerset

August 1999 


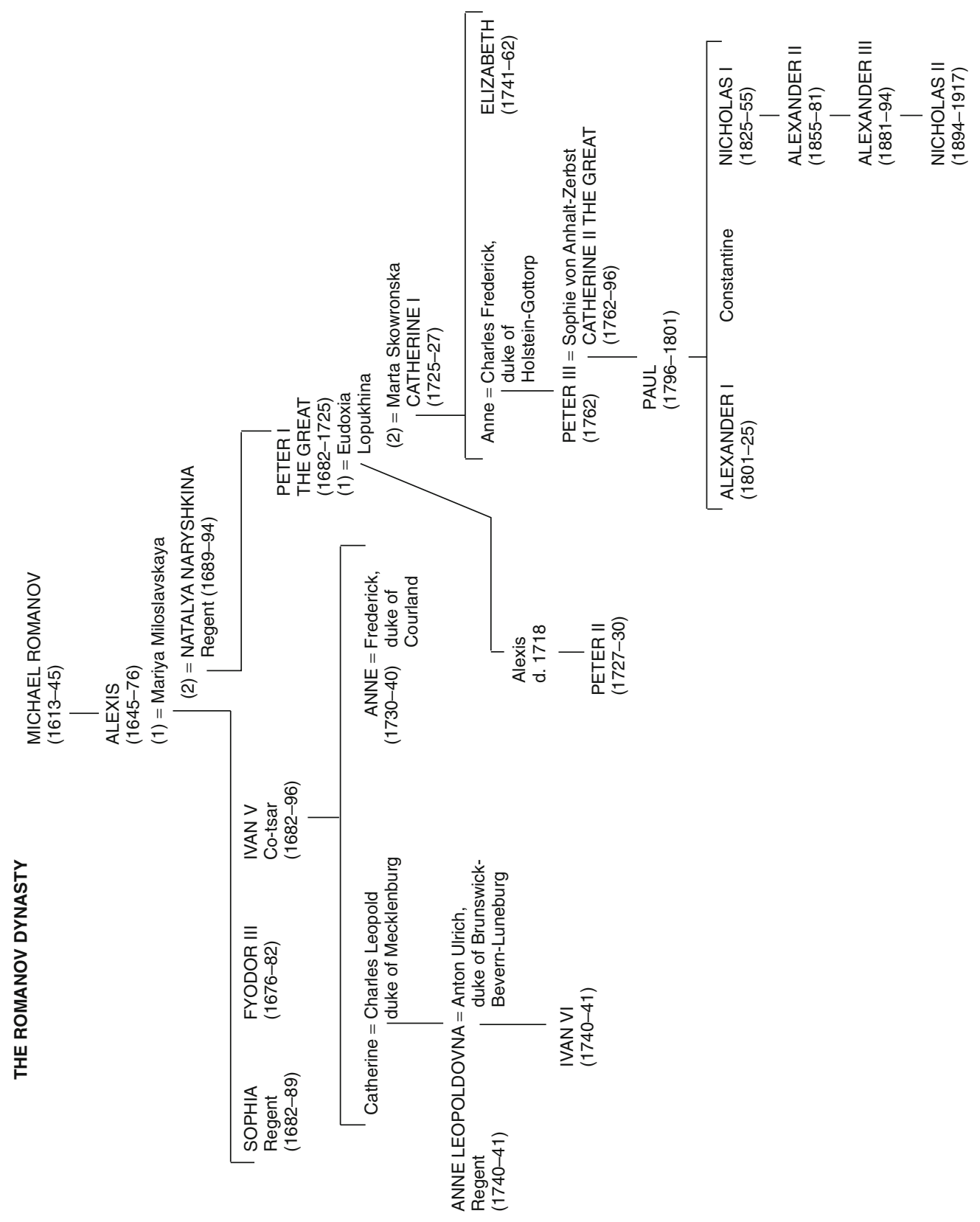




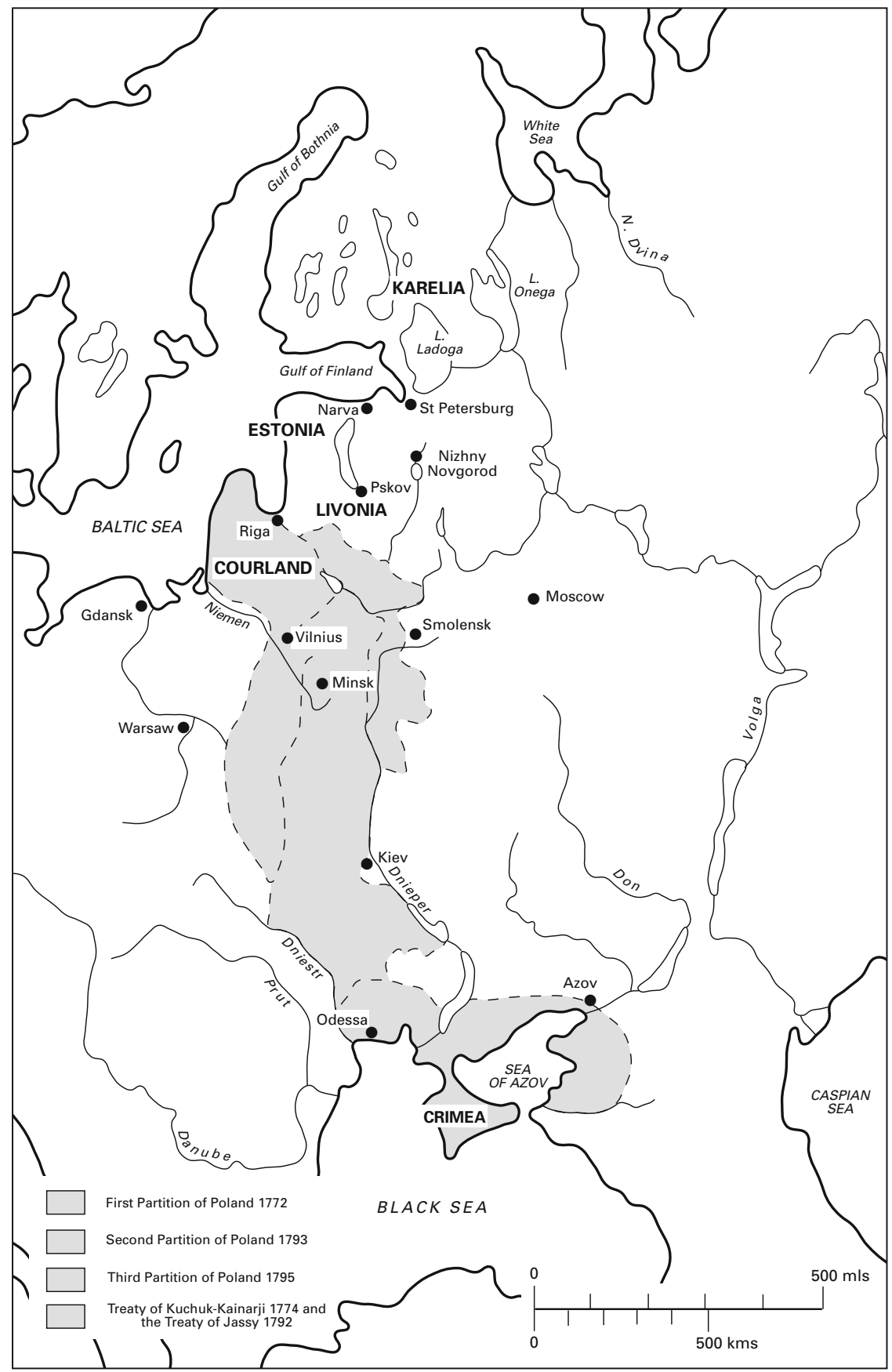

Map 1. Russian Expansion in the Reign of Catherine II (the Great) (1762-1796) 


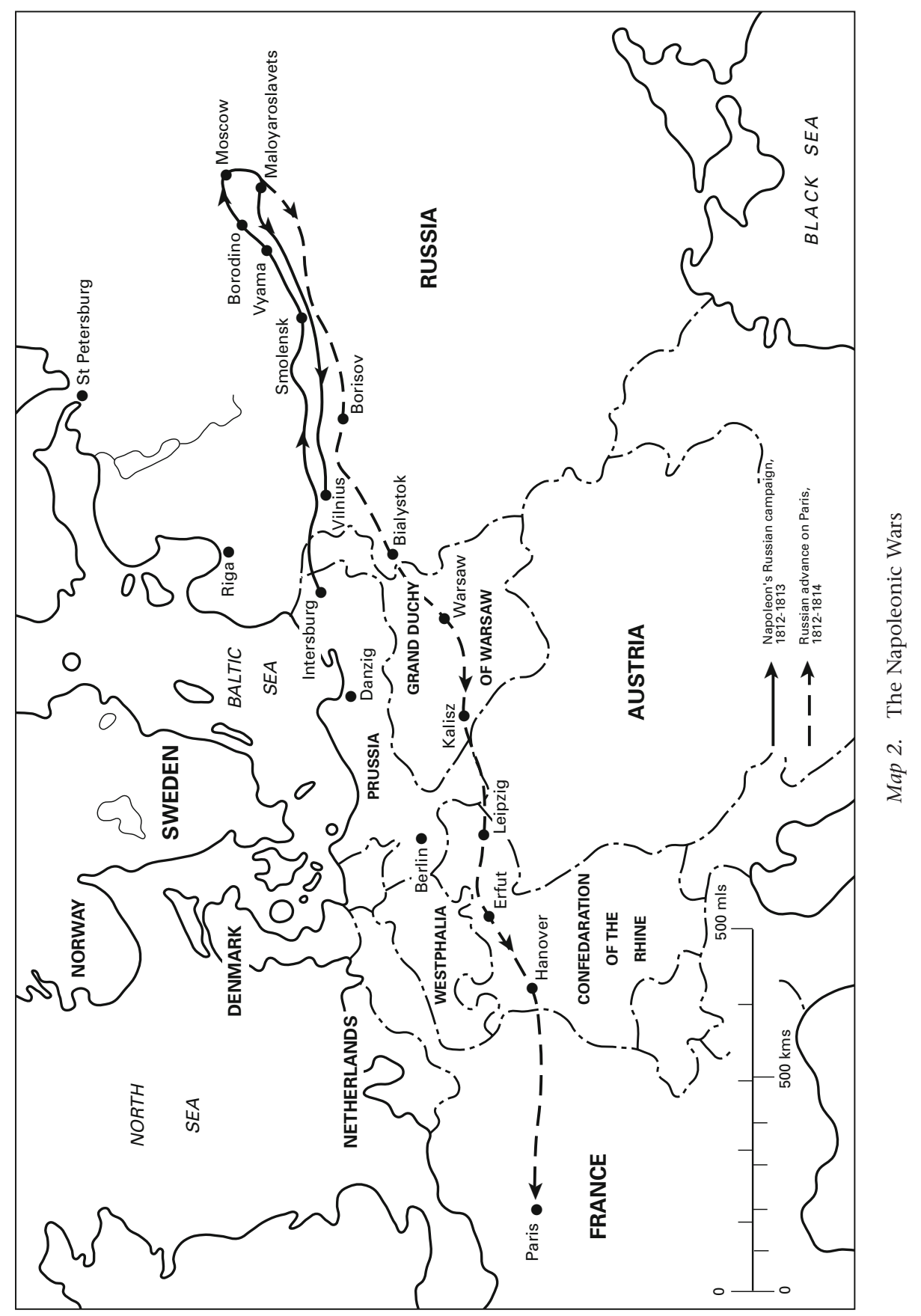




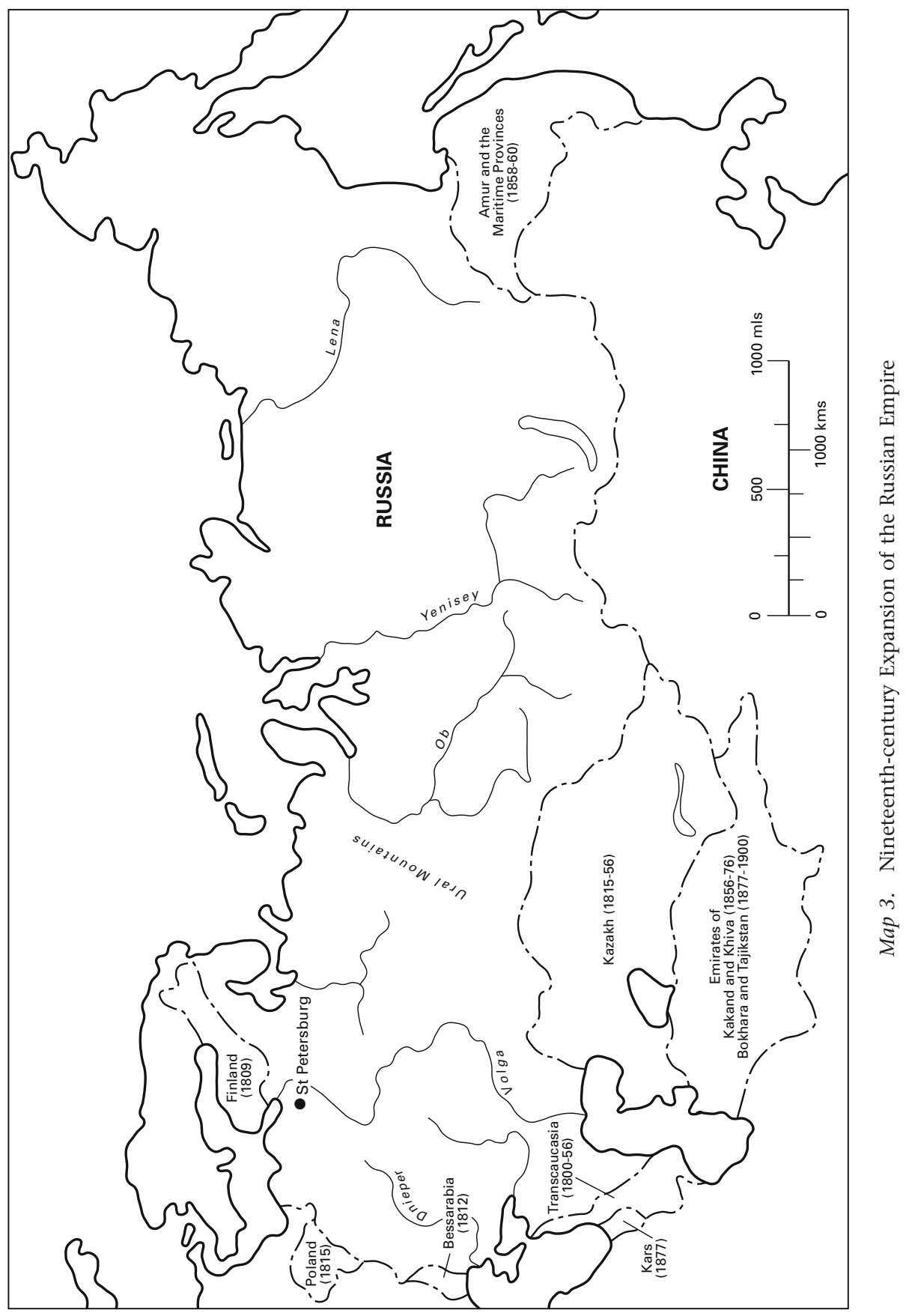




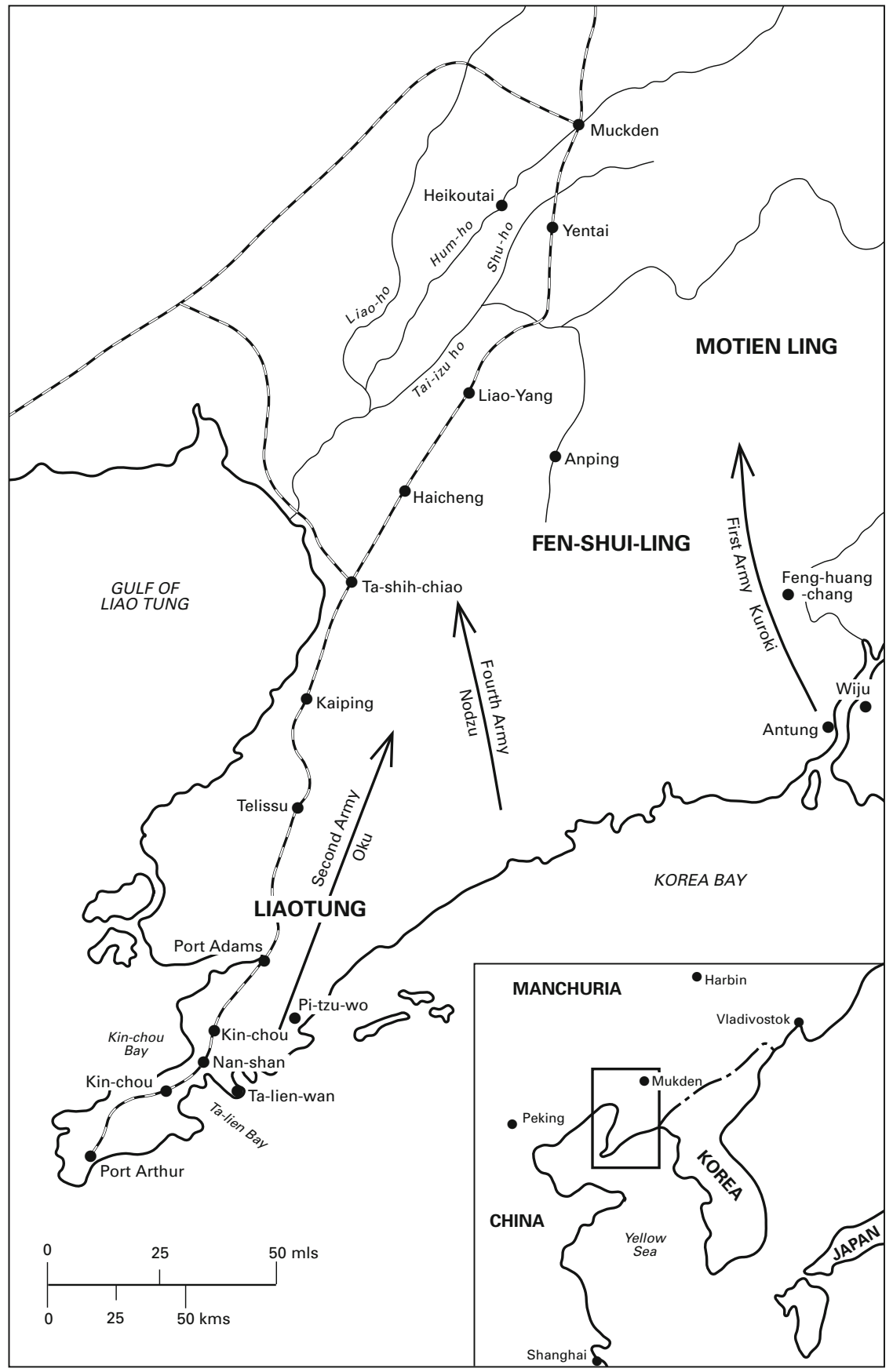

Map 4. Russo-Japanese War, 1904 


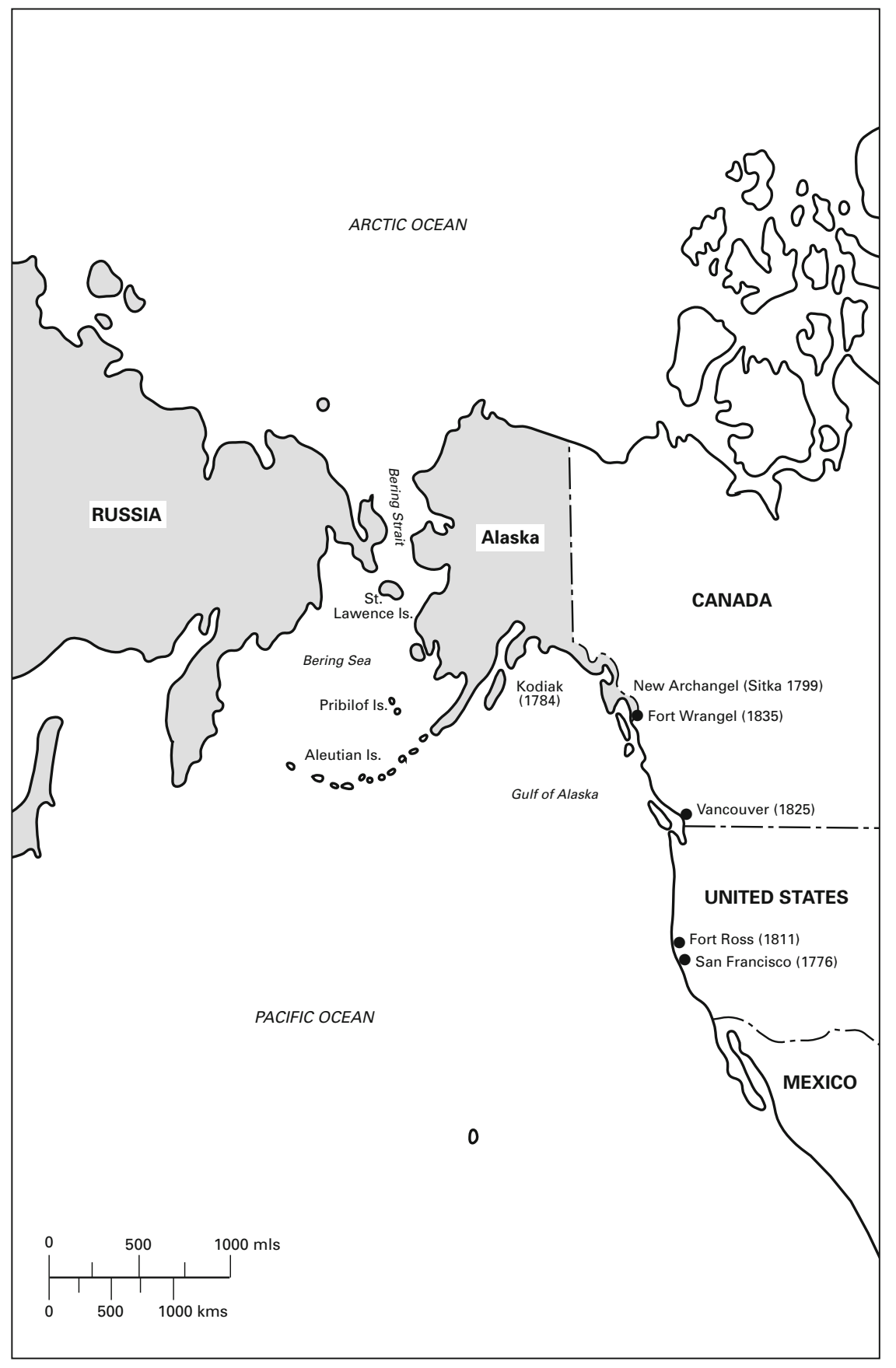

Map 5. Russia in America 


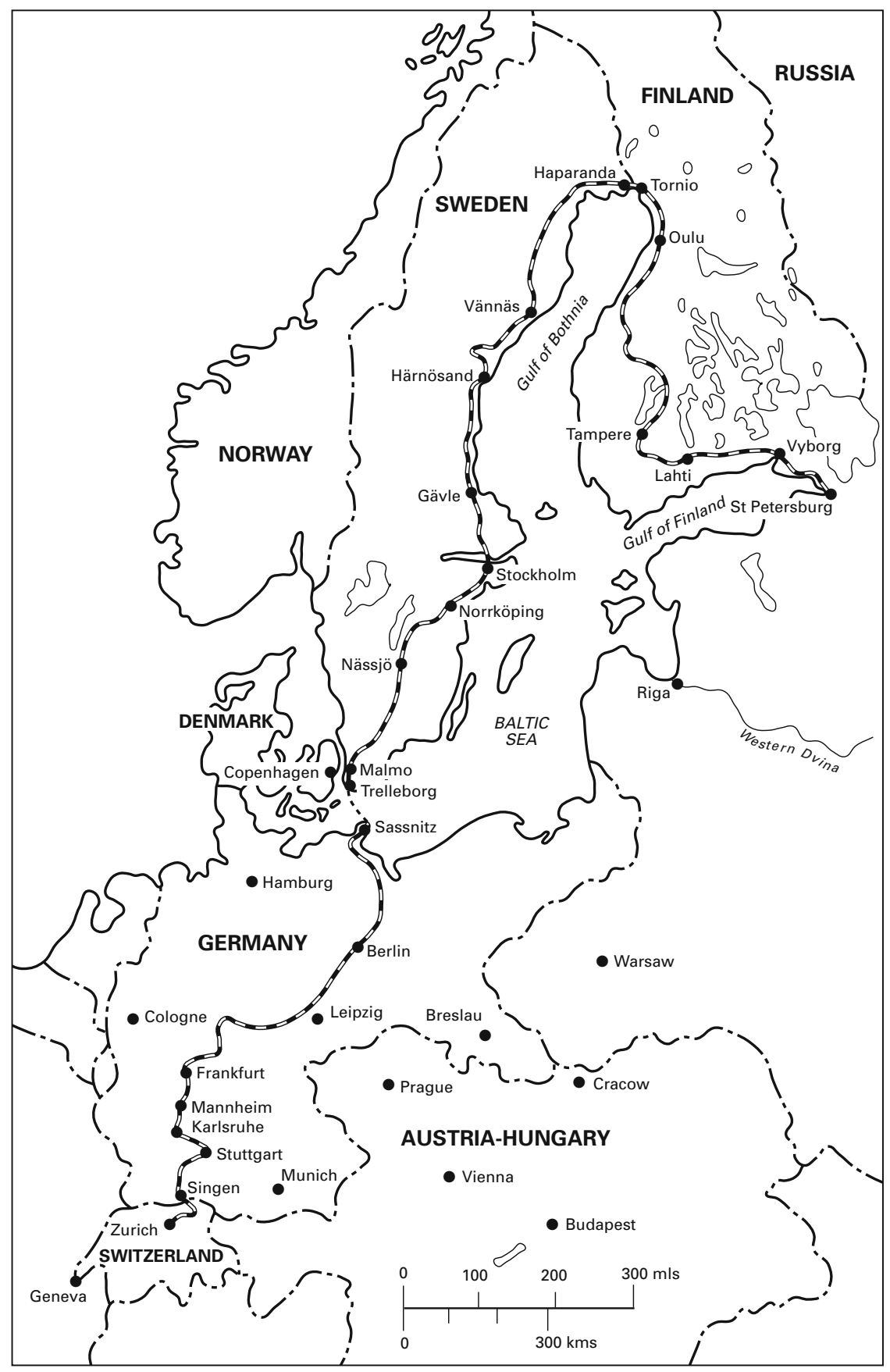

Map 6. Lenin's 'Sealed Train' Journey, 1917 